\title{
Studi Eksperimental Kuat Lentur Baja Ringan Profil C Sebagai Komponen Rangka Atap
}

\author{
Yudi Pranoto $^{1^{*}}$, Sujiati Jeprini ${ }^{2}$, Rio Haekal Offari ${ }^{3}$ \\ 1,2,3 Jurusan Teknik Sipil, Politeknik Negeri Samarinda \\ “yudipranoto@polnes.ac.id
}

\begin{abstract}
Cold-formed steel (CFS) has been extensively used in residential construction in Indonesia in recent years. Steel trusses also have great advantages in speeding up the construction process and reducing labor costs, since the lightweight of CFS makes such trusses much simpler to erect in comparison to wood trusses. As an alternative material to conventional wood truss construction, CFS trusses for residential roof systems capitalize on the many inherent benefits of steel and have great potential in both residential and commercial construction. The purpose of this study is to analyze how big the capacity of profile C75.35.0,75 CFS from three different products. From the results obtained as a result of the strong bending light steel C profile of each product. Powerful bending light steel profile C75.35.0,75 product Chi-Chi with span $1 \mathrm{~m}$ produced deflection of $14.78 \mathrm{~mm}$, the maximum load amounted to $86.80 \mathrm{Kg}$, whereas in the span of $1.5 \mathrm{~m}$ with the same products and specifications the resulting deflection of $52.95 \mathrm{~mm}$, the maximum load of $80.00 \mathrm{Kg}$. Powerful bending light steel profile C75.35.0,75 $1 \mathrm{~m}$ span Truss with products generated deflection of $20.76 \mathrm{~mm}$, the maximum load amounted to $151.33 \mathrm{Kg}$, whereas in the span of $1.5 \mathrm{~m}$ with the same products and specifications the resulting deflection of $43.67 \mathrm{~mm}$, the maximum load amounted to $126.33 \mathrm{Kg}$. Powerful bending light steel profile C75.35.0,75 product Kaso with span $1 \mathrm{~m}$ produced deflection of $21.01 \mathrm{~mm}$, the maximum load amounted to $164.00 \mathrm{Kg}$, whereas in the span of $1.5 \mathrm{~m}$ with the same products and specifications the resulting deflection of maximum load $43.33 \mathrm{~mm}$ amounted to $110.33 \mathrm{Kg}$. This result confirms that Kaso brand CFS products have the best load capacity, if compared two other products.
\end{abstract}

Keywords: cold frame, displacement, tension

\begin{abstract}
Abstrak
Baja ringan (CFS) telah banyak digunakan dalam konstruksi perumahan di Indonesia dalam beberapa tahun terakhir. CFS juga memiliki keuntungan besar dalam mempercepat proses konstruksi dan mengurangi biaya tenaga kerja, karena CFS lebih mudah untuk dirangkai dan pemasangan dibandingkan dengan struktur kayu. Sebagai bahan alternatif untuk konstruksi rangka kayu, CFS untuk sistem atap perumahan memiliki banyak kelebihan bila dibandingkan dengan rangka kayu dan memiliki potensi besar dalam konstruksi perumahan komersial. Pada penelitian ini bertujuan untuk mengetahui seberapa besar kekuatan lentur dari profil C75.35.0,75 baja ringan dari tiga produk yang berbeda. Dari hasil penelitian didapatkan hasil dari kuat lentur profil $\mathrm{C}$ baja ringan dari masing masing produk. Kuat lentur profil baja ringan C75.35.0,75 produk Chi-Chi dengan bentang $1 \mathrm{~m}$ dihasilkan lendutan sebesar 14,78 $\mathrm{mm}$ dan beban maksimal sebesar $86,80 \mathrm{~kg}$, sedangkan pada bentang $1,5 \mathrm{~m}$ dengan spesifikasi dan produk yang sama dihasilkan lendutan sebesar 52,95 mm dengan beban maksimal sebesar $80 \mathrm{~kg}$. Pada bentang $1 \mathrm{~m}$, untuk produk Truss dihasilkan lendutan sebesar 20,76 mm, beban maksimal sebesar 151,33 kg, sedangkan pada bentang 1,5 m dengan spesifikasi dan produk yang sama dihasilkan lendutan sebesar $43,67 \mathrm{~mm}$, beban maksimal sebesar 126,33 kg. Kuat lentur profil baja ringan C75.35.0,75 produk Kaso dengan bentang 1m dihasilkan lendutan sebesar 21,01 mm, beban maksimal sebesar $164 \mathrm{~kg}$, sedangkan pada bentang 1,5 m dengan spesifikasi dan produk yang sama dihasilkan lendutan sebesar 43,33 $\mathrm{mm}$, beban maksimal sebesar 110,33. Hasil ini menegaskan bahwa produk baja ringan merek Kaso memiliki kapasitas beban yang paling baik dibandingkan dengan dua produk yang lain.
\end{abstract}

Kata kunci: profil baja, lendutan, tegangan 


\section{Pendahuluan}

Baja ringan telah banyak digunakan untuk konstruksi perumahan di Indonesia. Baja ringan memiliki kelebihan dibandingkan dengan kayu. Diantaranya adalah dapat mempercepat proses konstruksi dan mengurangi biaya tenaga kerja. karena ringan baja ringan juga cocok untuk stuktur gedung karena dapat mengurangi berat sendiri struktur [1][2][3]. Selain memiliki kelebihan baja ringan juga mempunyai beberapa kelemahan yaitu tidak mudah dalam pembuatannya dan memerlukan pengawasan ekstra ketat dalam pelaksanaanya dan pembuatanya, selain itu juga baja ringan rawan terhadap bucling [4][5].

Beberapa penelitian tentang baja ringan telah dilakukan untuk menyelidiki kinerja baja ringan. Penelitian tersebut diantaranya adalah penelitian tentang kuat lentur baja ringan berlubang yang di bebani dengan beban terpusat Uzzaman et all [6]. Dar, M.A. et all [2], meneliti tentang balok baja ringan komposit. Jakab G. [5], dalam disertasinya menggunakan profil $\mathrm{C}$ untuk desain rangka kuda kuda baja.

Dengan latar belakang permasalahan seperti yang diuraikan diatas, maka penulis berinisiatif untuk meneliti profil baja ringan kanal dengan menguji baja ringan tersebut di laboraturium untuk melihat kuat lentur dan lendutan yang dapat diterima dari masingmasing produk. Lalu akan penulis tuangkan dalam laporan penelitian berupa perbandingan antara perhitungan teoritis dengan hasil pengujian yang penulis lakukan.

\section{Metoda Penelitian}

\subsection{Waktu Dan Tempat Penelitian}

Penelitian dilakukan pada bulan April 2019 di Laboratorium Teknik Sipil Politeknik Negeri Samarinda.

\subsection{Dimensi dan Variasi Benda Uji}

Jumlah benda uji sebanyak 18 buah benda uji ( 9 buah benda uji bentang 1,5 meter, dan 9 buah benda uji bentang 1 meter ). Masing masing 3 buah untuk 1 merek. Rincian benda

uji secra detail dapat dilihat dalam tabel dan gambar di bawah ini.

Tabel 1. Variasi Benda Uji

\begin{tabular}{lccc}
\hline \multirow{2}{*}{ Bentang } & \multicolumn{3}{c}{ Produk Baja Ringan (bh) } \\
\cline { 2 - 4 } & Chi-chi & Truss & Kaso \\
\hline 1 meter & 3 & 3 & 3 \\
$1,5 \mathrm{~m}$ & 3 & 3 & 3 \\
\hline
\end{tabular}

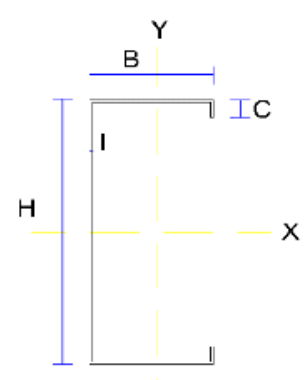

Gambar 1. Ukuran profil C

Tabel 2. Spesifikasi Profil Baja Ringan Canal

\begin{tabular}{clcc}
\hline No & \multicolumn{1}{c}{ Item } & Ukuran & Satuan \\
\hline 1 & Tinggi (H) & 75 & $\mathrm{~mm}$ \\
2 & Lebar (B) & 32 & $\mathrm{~mm}$ \\
3 & Panjang bengkokan & 8 & $\mathrm{~mm}$ \\
4 & Tebal (I) & 0,75 & $\mathrm{~mm}$ \\
5 & Luas Tampang & 1,14 & $\mathrm{~mm}$ \\
6 & Berat (w) & 0,89 & $\mathrm{Kg} / \mathrm{m}$ \\
\hline
\end{tabular}

Tabel 3. Spesifikasi Material Dasar Profil Canal Baja Ringan

\begin{tabular}{clcc}
\hline No & \multicolumn{1}{c}{ Item } & Ukuran & Satuan \\
\hline 1 & Mutu Baja & G-550 & \\
2 & Tegangan leleh & 550 & Mpa \\
3 & Modulus elastisitas & $2,1 \times 10^{5}$ & $\mathrm{~mm}$ \\
4 & Kadar alumunium & 55 & $\%$ \\
5 & Kadar Seng & 43,5 & $\%$ \\
6 & Silicon & 1,5 & $\%$ \\
\hline
\end{tabular}




\subsection{Tahapan Penelitian}

Tahapan penelitian ini dilakukan secara rinci sesuai dengan flow chart pada Gambar 2.

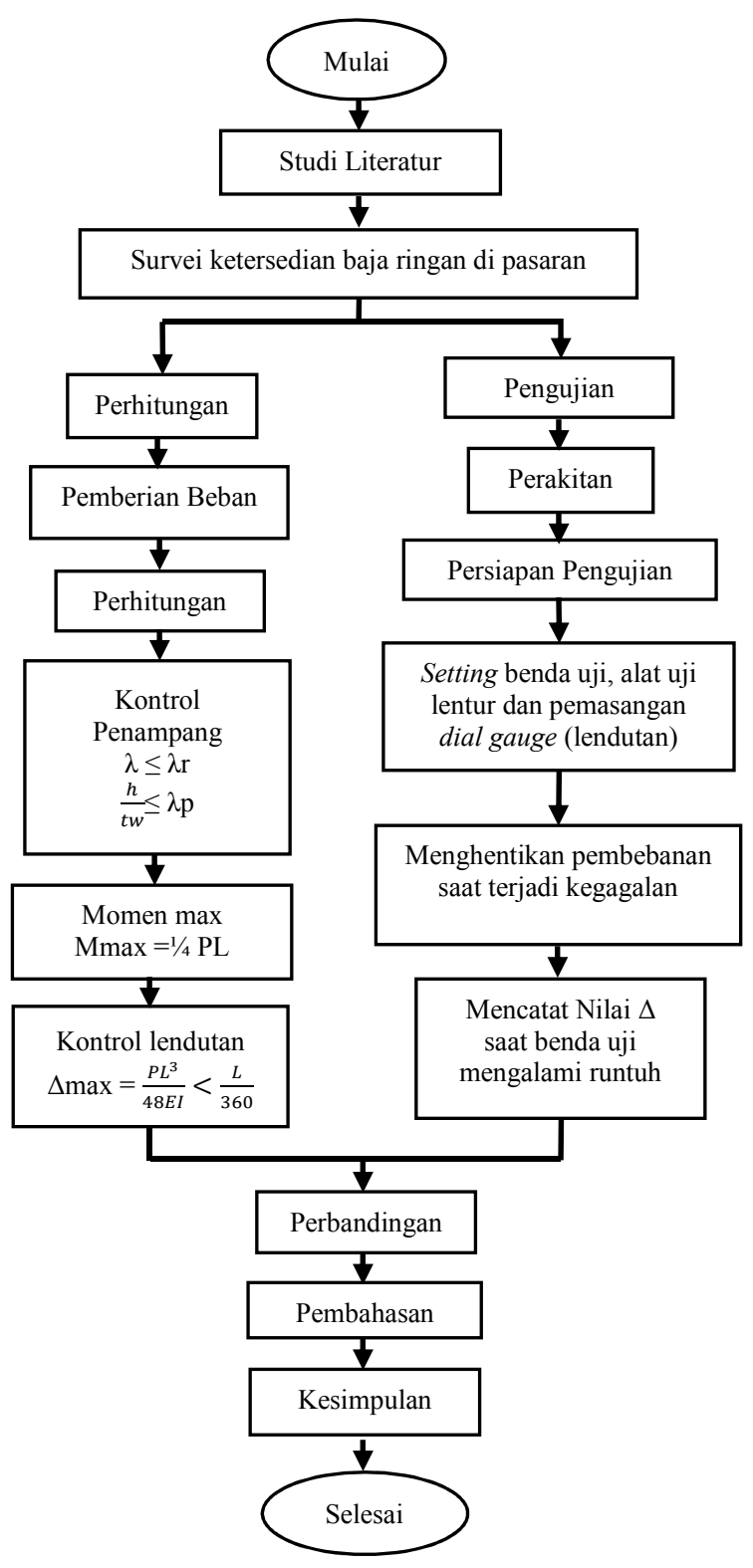

Gambar 2. Flow Chart Penelitian

\subsection{Set Up Pengujian}

Peralatan yang dipergunakan untuk penelitian adalah 1 set alat uji lentur, data logger, load cell, hydraulic jack dan LVDT. Secara rinci set up pengujian lentur dapat dilihat pada Gambar 3.

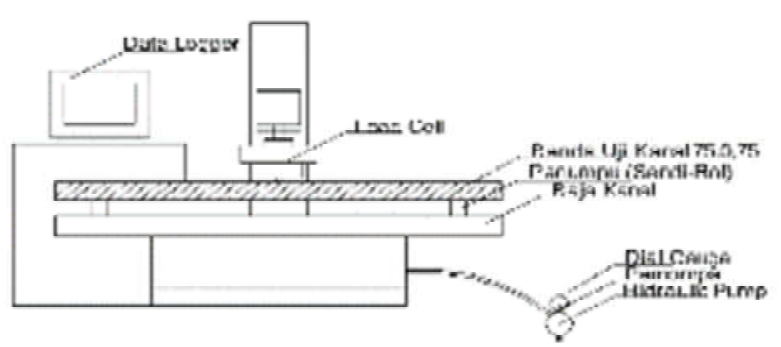

Gambar 3. Set Up Pengujian

\subsection{Pengujian di laboratorium}

Pengujian dilakukan di laboratorium Teknik Sipil, Politeknik Negeri Samarinda (Gambar 4).

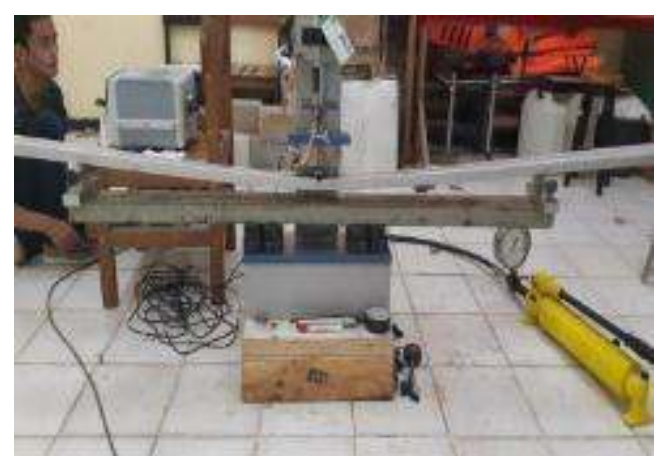

Gambar 4. Pengujian di laboratorium

\subsection{Perhitungan secara analitis dan SAP 2000}

- Beban Maximum (P max)

$$
\begin{aligned}
\mathrm{P} \max & =\text { Atarik } \times \mathrm{fd} \\
& =12 \times 17,04 \\
& =204,44 \mathrm{Kg}
\end{aligned}
$$

- Lendutan

$$
\begin{aligned}
\Delta y= & \frac{P L^{3}}{48 E I x}<\frac{L}{240} \\
= & \frac{204,44 \mathrm{Kg} \times\left(1000^{3}\right) \mathrm{mm}}{48 \times 20000 \frac{\mathrm{Kg}}{\mathrm{mm}^{2}} \times 85037,39 \mathrm{~mm}^{4}} \\
& <\frac{1000 \mathrm{~mm}}{240} \\
= & 2,50 \mathrm{~mm}<4,17 \mathrm{~mm}
\end{aligned}
$$


Dari data beban maksimum yang didapat dari hasil analitis kemudian dijadikan beban terpusat pada SAP 2000 (tampak pada Gambar $5)$.

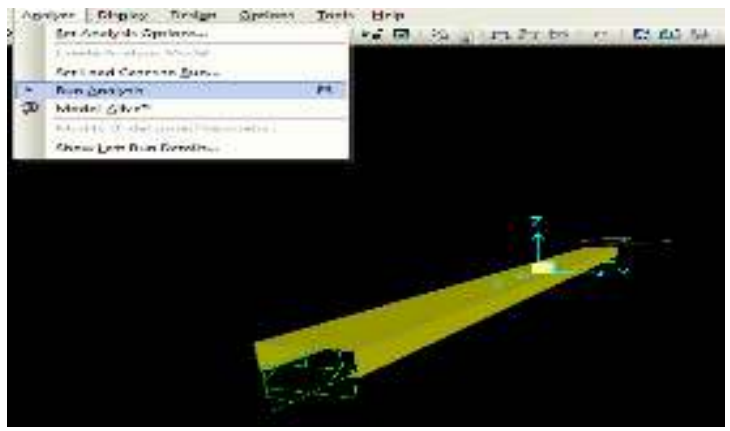

Gambar 5. Modeling benda uji menggunakan SAP 2000

\section{Hasil Penelitian}

Dari hasil pengujian didapatkan lendutan dan beban maksimum yang dapat di tahan oleh profil baja ringan tersebut.

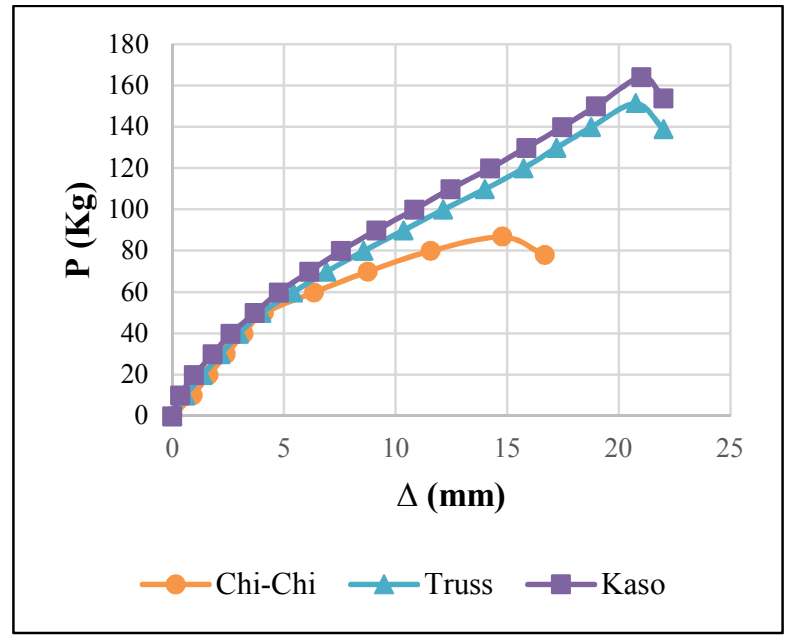

Gambar 6. Grafik hubungan antara beban dan lendutan pada bentang $1 \mathrm{~m}$

Dari hasil grafik hubungan antara lendutan dan beban pada bentang $1 \mathrm{~m}$ di atas dapat dilihat perilaku yang terjadi pada ketiga merk tersebut. Jika dilihat dari lendutan izinnya $(\Delta$ izin $=4,17 \mathrm{~mm})$, maka nilai beban $(\mathrm{P})$ terbesar adalah merk kaso dengan beban 54,80 kg sedangkan beban terkecil terjadi pada merk Chi-chi dengan beban maksimum yang bisa ditahan sebesar $50,70 \mathrm{~kg}$.
Sedangkan lendutan yang terjadi pada saat beban maksimum lendutan $(\Delta)$ terbesar adalah merek Kaso dengan lendutan 21,01 mm sedangkan yang terkecil adalah Chi-Chi seb esar $14,78 \mathrm{~mm}$.

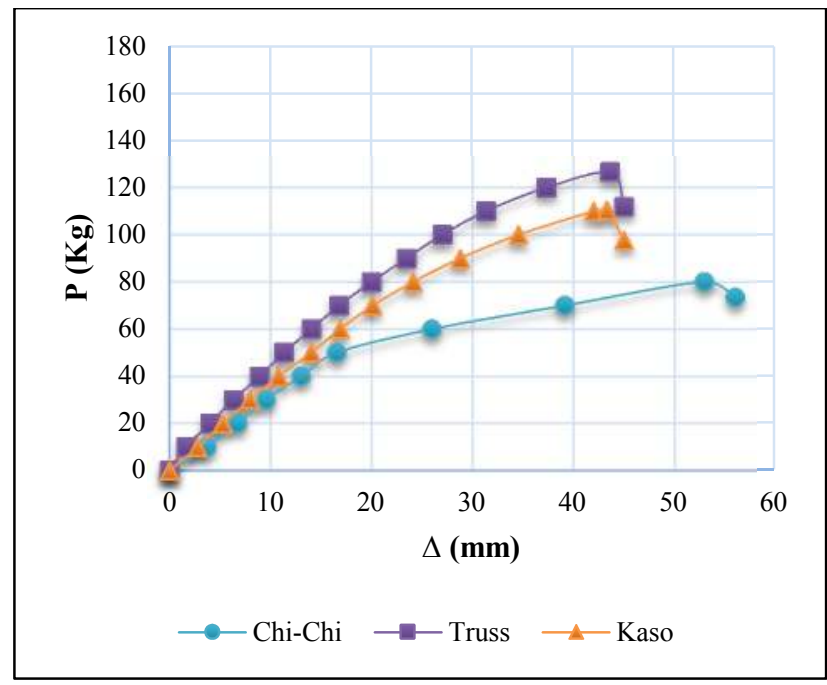

Gambar 7. Grafik hubungan antara beban dan lendutan pada bentang $1,5 \mathrm{~m}$

Dari hasil grafik hubungan antara lendutan dan beban pada bentang 1,5 $\mathrm{m}$ di atas dapat dilihat perilaku yang terjadi pada ketiga merk tersebut. Jika dilihat dari lendutan izinnya $(\Delta \mathrm{izin}=6,25$ $\mathrm{mm})$, maka nilai beban $(\mathrm{P})$ terbesar adalah merk Truss $=29,90 \mathrm{Kg}$ sedangkan beban terkecil terjadi pada merk Chi-Chi $=18,00 \mathrm{Kg}$. Sedangkan lendutan $(\Delta)$ terbesar adalah merek Chi-Chi sebesar $52,95 \mathrm{~mm}$ sedangkan yang terkecil merek Kaso sebesar 43,33 mm.

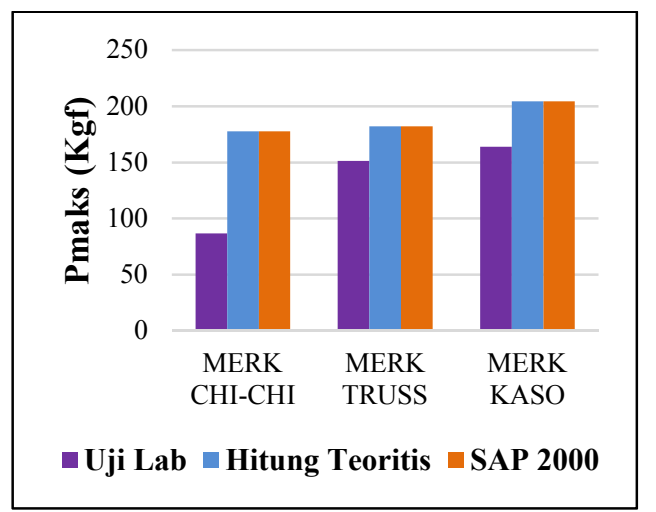

Gambar 8. Grafik perbandingan beban maksimum secara analitis dan hasil uji lab pada bentang $1 \mathrm{~m}$ 


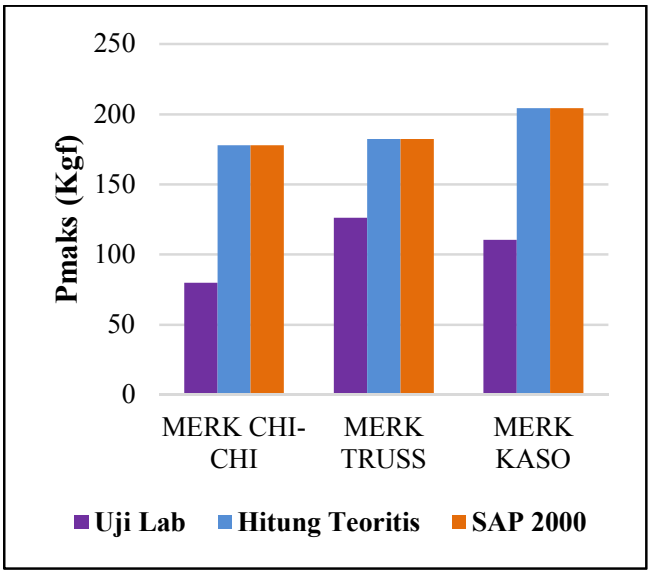

Gambar 9. Grafik perbandingan beban maksimal secara analitis dan hasil uji lab pada bentang 1,5 m

Dari hasil perbandingan nilai beban maksimal (Pmaks) pada bentang $1 \mathrm{~m}$ dan 1,5 m antara pengujian laboraturium, hitung manual dan pengecekan SAP dapat dilihat bahwa pada hasil uji lab memiliki nilai yang lebih kecil dibandingkan dengan nilai perhitungan manual dan pengecekan SAP. Sedangkan untuk nilai hasil perhitungan manual dan pengecekan SAP memiliki nilai yang sama. Hal ini bisa disebabkan karena nilai properties material baja yang tidak sesuai dengan kondisi benda uji. Untuk nilai beban maksimum terbesar secara teoritis pada 3 metode terdapat pada merk Kaso.

\section{Kesimpulan}

Berdasarkan hasil analisis dan pengujian di laboratorium, dapat ditarik kesimpulan sebagai berikut :

1. Baja ringan hasil pengujian di laboratorium yang mampu menahan beban terbesar pada bentang 1 meter adalah merk kaso dengan beban $54,80 \mathrm{~kg}$ dengan displacement 21,01 $\mathrm{mm}$, sedangkan pada bentang 1,5 meter adalah merk Truss yaitu sebesar 29,90 Kg dengan displacement 43,67 $\mathrm{mm}$.

2. Terdapat perbedaan beban maksimum yang dapat di tahan oleh baja ringan antara teoritis dengan uji laboratorium yaitu rata rata sebesar $29,30 \%$.

\section{Saran}

Diperlukan adanya penelitian lebih lanjut untuk variasi bentang yang lebih panjang sesuai kebutuhan lapangan.

\section{Daftar Pustaka}

[1] L. Xu, H. Min, and R. M. Schuster, "Optimum design of cold formed steel residential roof trusses," Int. Spec. Conf. Cold-Formed Steel Struct. Recent Res. Dev. Cold-Formed Steel Des. Constr., pp. 393410, 2000.

[2] M. Adil Dar, N. Subramanian, M. Anbarasu, A. R. Dar, and J. B. P. Lim, "Structural performance of cold-formed steel composite beams," Steel Compos. Struct., vol. 27, no. 5, pp. 545-554, 2018.

[3] R. Landolfo, "Cold-Formed Steel Structures in Seismic Area: Research and Applications," VIII Congr. Construção Metálica e Mista, Guimarães, pp. 3-22, 2011.

[4] C. Rameshbabu, G. Venkatesan, and N. P. Vignesh, "Analytical Studies on Distortional Buckling of Cold Formed Stainless Steel Columns," Int. J. Civ. Eng. Build. Mater., vol. 3, no. 2, 2013.

[5] G. JAKAB, "Analysis and Design of ColdFormed C-Section Members and Structures," Thesis Res., p. 115, 2009.

[6] A. Uzzaman, J. B. P. Lim, D. Nash, and K. Roy, "Cold-formed steel channel sections under end-two-flange loading condition: Design for edge-stiffened holes, unstiffened holes and plain webs," Thin-Walled Struct., vol. 147, no. May 2019, p. 106532, 2020. 